This is an electronic reprint of the original article. This reprint may differ from the original in pagination and typographic detail.

Author(s): Pučètaitè, Raminta; Novelskaitè, Aurelija; Lämsä, Anna-Maija; Riivari, Elina

Title: $\quad$ The Relationship Between Ethical Organisational Culture and Organisational Innovativeness : Comparison of Findings from Finland and Lithuania

Year: $\quad 2016$

Version:

Please cite the original version:

Pučètaitè, R., Novelskaitè, A., Lämsä, A.-M., \& Riivari, E. (2016). The Relationship

Between Ethical Organisational Culture and Organisational Innovativeness :

Comparison of Findings from Finland and Lithuania. Journal of Business Ethics, 139(4), 685-700. https://doi.org/10.1007/s10551-016-3051-8

All material supplied via JYX is protected by copyright and other intellectual property rights, and duplication or sale of all or part of any of the repository collections is not permitted, except that material may be duplicated by you for your research use or educational purposes in electronic or print form. You must obtain permission for any other use. Electronic or print copies may not be offered, whether for sale or otherwise to anyone who is not an authorised user. 
Reference code: ORGINN

Type: original article

\title{
The relationship between ethical organisational culture and organisational innovativeness: Comparison of findings from Finland and Lithuania
}

\begin{abstract}
The paper explores the interrelations between ethical organisational culture and organisational innovativeness in two different socio-cultural contexts, Finland and Lithuania. According to the Global Innovation Index 2013, Finland ranked 6th and Lithuania 40th in terms of the national capacity to produce innovations. Prior research by Riivari and Lämsä (2014) and Riivari et al. (2012) argues the importance of the ethical dimension of organisational culture in fostering the organisational capacity to innovate. In this paper, a different context is taken to test hypothesized differences between the two multidimensional phenomena. The paper discusses the findings of 2 surveys in Finnish and Lithuanian public organisations (respectively, $\mathrm{n}_{\mathrm{FI}}=477$ and $\mathrm{n}_{\mathrm{LT}}=757$ ). Data analysis shows that ethical organisational culture affects organisational innovativeness, in particular process and behaviour innovativeness in both organisations. The findings suggest that some ethical virtues such as congruency of management, discussability and clarity can be explained by an institutional rather than sociocultural context. However, the effect of transparency and sanctionability in the Finnish organisation and congruency of supervisors, supportability and feasibility in the Lithuanian organisation rests on peculiarities of a socio-cultural context.
\end{abstract}

Key-words: corporate ethical virtues, ethical organisational culture, Finland, Lithuania, organisational innovativeness, public organisation, socio-cultural context. 


\section{Introduction}

Organisational innovativeness as an organisational capability to create new ideas and solutions, experiment, and engage in creative processes (Lumpkin and Dess, 1996) is considered a key element in innovation development (Wang and Ahmed, 2004; Yu et al., 2013), organisational performance (Cho and Pucik, 2005), and regional competitiveness (Broekel and Brenner, 2011). It urges researchers and organisations to identify the factors determining its development and growth. This applies not only to private companies but also to public organisations, which are under pressure to use tax-payers' money responsibly and satisfy public interests by providing innovative solutions to social and environmental problems. This pressure has resulted in reforms of the public sector, many related to the concept of New Public Management (hereafter - NPM, Hood, 1991), and demand deliberate changes and renewals in the processes and structures of public organisations to ensure better provision of services and products to society and optimal organisational performance (Politt and Bouckaert, 2011). These changes have resulted in attempts to adopt benchmarking, quality management, management by objectives and other management ideas as NPM innovations for public organisation management (Hansen, 2011) with various rates of success, leading us back to the question of the factors influencing innovativeness and innovations. Here we make a distinction between the two terms. We consider innovativeness as the capability to produce innovations, the number, character, developmental extent and implementation of which may at the same time vary (cf. Tajeddini et al., 2006).

A number of studies have argued that organisational culture is an important condition for organisational innovativeness (Martins and Terblanche, 2003; Mumford, 2000; Sarros et al., 2008; Valencia et al., 2010) and, as Büschgens et al. (2013, pp. 763-4) maintain, “[b]y now, it 
is common sense that organisational culture is a key to innovation success". However, despite the recognition of organisational culture as a factor influencing organisational capability to innovate, there is still little agreement on the type of organisational culture that helps organisations to be innovative (Büschgens et al., 2013). Nevertheless, one aspect of organisational culture that scholars agree is important in this respect is the congruence of values among organisation's members. Prior research highlights organisational values of trust and empowerment, tolerance of error, organisational learning, open communication, participative decision-making and cooperation as determinants of organisational innovativeness (Büschgens et al., 2013; Hurley and Hult, 1998; Keith and Frese, 2011; Martins and Martins, 2002; Martins and Terblanche, 2003). They characterise an organisational context that motivates employees to engage in exploration and experimenting, knowledge sharing and creation and, thus, account for innovation development (Ellonen et al., 2008; Sankowska, 2013). However, the capability to innovate includes a risk-taking component, which may sometimes prompt individuals to think and act innovatively yet irresponsibly and unfairly to others, disregarding the long-term perspectives of organisational development and society (Baucus et al., 2008; Gino and Ariely, 2011). Therefore, urge for organisational innovativeness in public organisations has ethical implications (Jordan, 2013). The search for innovative solutions to optimise organisational performance and, for example, reduce public costs in administering systems, may have unintended consequences such as growing unemployment because employees were substituted by technologies or marginalising certain social groups such as low-income households which cannot afford access to technological innovations such as Internet-based public services. Therefore, an organisation's attentiveness to ethical values such as honesty, fairness, justice, integrity, (mutual) respect, equality and openness when practicing innovativeness is particularly important for gearing it towards the common good and securing public trust. In particular, the importance of the 
ethical aspects for practising innovativeness grows in public organisations with mission to ensure equality and social welfare for its citizens.

Despite the apparent importance of the ethical dimension of organisational culture, little empirical research has been carried out on the interrelation between ethical organisational culture and organisational innovativeness both in the private and public sectors. This gap has been addressed in recent studies by Riivari et al. (2012), Riivari and Lämsä (2014), who have found a positive interrelation between ethical organisational culture and organisational innovativeness. Their studies were carried out in the Finnish society, which is strongly dominated by values of accountability, equality, trustworthiness, honesty and justice (Helkama and Seppälä, 2006; Kujala, 2004; 2010; Lämsä and Viljanen, 2014). However, there is no knowledge whether the same interrelation is valid in a different socio-cultural context such as Lithuania. Lithuania is a post-Soviet society where historically private interest, authenticity and the originality of the people were suppressed, while free-riding and opportunistic behaviour were widespread (Morgan, 1998), and following dual norms was the usual technique for survival (Ivanauskas, 2011). Hence, it is characterized by low trust, low organisational commitment, and an attitude to organisational values as declarative (Lämsä and Pučètaitè, 2006; Pučètaitė et al., 2010; Vasiljevienė, 2000; Žiliukaitė et al., 2006). Due to a lack of trust among society's members, a willingness to share ideas and cooperate on developing new services or improving processes may be limited in this context. These sociocultural differences may affect organisations' capability to innovate, which is also implied by the countries' ratings in the Global Innovation Index 2013, where Finland is ranked 6th and Lithuania 40th in terms of their capacity to produce innovations.

Furthermore, management of public sector organisations in the chosen societies may also be significantly different. According to Politt and Bouckaert (2011, p. 73), in Finland, public 
organisations are managed by "consensual, often meso-corporatist styles of governance", and the services they provide are considered a source of social welfare (Oinas, 2005). In Lithuania many public organisations are still hierarchical and autocratic, although significant reforms were made before and after accession to the EU in 2004, in particular, by changing the general attitude to citizens towards seeing them as customers of public institutions. However, in public discourse there is a strong opinion that the public sector is wasteful, and the level of institutional trust in major public organisations has been low for decades (Hlepas, 2013; Kuokštis, 2012).

Therefore, in this paper we are interested in possible differences of the ethical virtues of organisational culture that account for particular types of organisational innovativeness in public organisations operating in two different socio-cultural contexts. In this way, we attempt to make two contributions to the academic literature in the field of factors influencing organisational innovativeness. Firstly, we investigate the impact of ethical organisational culture on organisational innovativeness and, secondly, we focus on particular organisational virtues that account for particular types of organisational innovativeness. To our knowledge, no studies to date have compared the relationship between the ethical culture of organisations and organisational innovativeness in different socio-cultural contexts. Consequently, we specifically extend existing knowledge of the relationship by making a comparison between Finland and Lithuania. Throughout this paper, we develop hypotheses and test them in two public sector organisations in Finland and Lithuania. The findings of this study lead to a discussion of how managers of public organisations can foster more favourable contexts for organisational innovativeness which enhances the common good.

\section{Conceptual background of the study and hypotheses}


Organisational culture is one of the most researched topics in organisation studies, approached using a variety of theories, methodologies, epistemologies and political orientations (Alvesson, 2011). On the one hand, it is regarded as a system of negotiated symbols, shared and learnt meanings and understandings, which are constructed through language and social interaction, and, on the other hand, as shared beliefs, values and norms which are measurable and manageable and linked to action effects (Alvesson, 2011, p. 14). In this paper, we take the latter view and define organisational culture as a combination of formal structures, systems, and organisational practices and informal, unspoken, taken-for-granted assumptions, norms and behavioural modes that may go unreflected in organisational life (Trevinõ et al., 1998; Schein, 1990). Following this logic, the formal component of ethical organisational culture is constituted by ethics management systems with particular tools such as ethics codes, ethics training and ethics auditing and so on, leadership and human resource management practices, and the informal component of assumptions, beliefs, values, behavioural norms, role models and stories that are ethically loaded (Huhtala et al., 2013; Kaptein, 2010; Trevinõ et al., 1998). We maintain that ethical organisational culture is characterised by the congruence of formal and informal components and promotes not only organisational goals but also the common good. From this perspective, organisational cultures, which only have formal elements such as ethics management tools but do not encompass ethical values in their daily operations, are not really ethical (cf. MacLean et al., 2015).

Despite the attention from scholars towards ethical organisational culture, empirical research on its interrelation with innovativeness is not common. Although studies on the association of organisational culture and innovation can be found (Prajogo and McDermott, 2011; Valencia et al., 2010; cf. Büschgens et al., 2013), most of them focus on the competing values framework by Quinn and Spreitzer (1991), overlooking its ethical dimension. In this study, we apply the Corporate Ethical Virtues (hereafter - CEV) model, a multidimensional 
construct and measurement of the ethical culture of an organisation (Kaptein, 2008). The model rests on a virtue-based theory of business ethics (Solomon, 2004) that has its roots in Aristotle's virtue ethics and considers certain characteristics or virtues as indicators of an ethical character. This theory views organisations as morally and socially responsible agents, and maintains that organisations as communities nourish individual virtues through corporate environments directed towards integrity or, in other words, moral excellence. In this way, an organisation creates a community of practice whose members develop and/or possess virtuous character traits by duly fulfilling their responsibilities and contributing to the common good (Solomon, 2004). Moreover, virtuous organisations possess the capability to produce benefits for multiple stakeholders intentionally rather than by accident.

Consequently, according to Kaptein (2008), the ethicality or virtuousness of an organisation can be determined by the extent to which the organisational culture stimulates the organisation's members to act ethically and prevents them from unethical behaviour. The CEV model consists of eight virtues: clarity, congruency of supervisors, congruency of management, feasibility, supportability, transparency, discussability and sanctionability. In an ethical organisation, these virtues are implemented and maintained both by organisational practices and individual decisions and actions. Clarity refers to an organisation's explicit expectations of its employees that they will act ethically. In practice, this virtue manifests itself through codes of conduct, the organisation's members following the rules with integrity, and concerns with the organisation's stakeholders. The congruency of supervisors and management refer to how supervisors and management act as role models for the employees. These virtues stand for integrity demonstrated by the organisation's leadership (Bauman, 2013). Ethical organisations are led by people who consider ethics as important and embody ethical values in their decisions and behaviour. Moreover, professional leaders are expected to follow professional norms and standards, which prioritise societal welfare over individual and 
organisational interests (Vasiljevienè, 2000). Feasibility is related to the resources allocated by an organisation so that its employees would be able to follow the normative expectations. This virtue is reflected in time, information, training and/or finance given by the organisation to enable its employees to act responsibly and in an environment that is free from coercion to compromise individual integrity or bypass clearly set rules. Supportability denotes organisational support and encouragement to follow the norms. In practice, this means reciprocal respect, trust and sincere striving for the common good in a community of practice. Transparency is the degree to which the consequences of ethical or unethical employee behaviour is perceived by the employees themselves and their colleagues. It means that the organisation has risk management and monitoring systems to ensure that detrimental behaviour does not go unnoticed. Discussability concerns opportunities for employees to be open and sincere when facing ethical issues and the possibility to discuss them. Ethical organisations are not naïve agents; therefore, ethics hotlines or round-table discussions that are meant to raise moral concerns may be integral elements of their character. They welcome constructive criticism and feedback-giving, and take mistakes as opportunities to learn rather than for punishing the guilty. Ethical organisations take responsibility for processes, which may have determined detrimental individual behaviour. The last virtue, sanctionability, relates to the degree employees perceive that unethical behaviour is punished and ethical behaviour rewarded in the organisation. In practice, sanctionability is reflected through criteria integrated in human resource management practices such as (annual) evaluation, promotion or dismissal. Ethical organisations promote those individuals who have a reputation for ethical behaviour, take disciplinary actions for unethical actions, set preventive mechanisms to eliminate the possibility of such repetitive behaviour and incite due expectations from the employees. In this way, they create a corporate mind-set that relates expectations of the good life by practising ethical virtues and developing the virtue of integrity that completes an organisation as an ethical agent. 
The CEV model has an outspoken ethical dimension. For example, clarity is a precondition for an individual's security and the autonomy to make decisions with integrity; thereby, making it possible to assume responsibility for his or her actions. Congruency of supervisors and management are related to the value of integrity, which is a pre-condition for trust development in an organisation (Mayer et al., 1995). Feasibility demonstrates the organisation's respect for its employees and ensures their dignity at work: when an organisation provides its employees with the resources to fulfil their responsibilities, this indicates an appreciation of basic human dignity (Wieland, 2003). Supportability rests on interpersonal trust and reciprocity and strengthens the individual's identification with the organisational values, norms and rules (Kaptein, 2008). Transparency, discussability and sanctionability denote equality among employees disregarding their position and civic attitude towards violations of ethical norms. According to Kaptein (2008), the first three values embody the organisational capacity of self-regulation; feasibility and supportability constitute the self-providing capacity of organisation; and the last three virtues denote the self-correcting capacity. All these capacities are important for ensuring the ethical character of an organisation.

The other concept used in this study, organisational innovativeness, is also regarded as a multidimensional construct based on the conceptualisation and measurement presented by Wang and Ahmed (2004). Their model includes five dimensions of organisational innovativeness (hereafter - ON): product, market, process, behaviour and strategy. Product innovativeness relates to the newness of an organisation's products and services. Examples of product innovativeness include the organisational capability to initiate new programmes or develop technologies that enhance the service quality and quality of life for citizens. Market innovativeness concerns new approaches to reaching target audiences. Market innovativeness 
is manifested, for example, by communication techniques that try to reach citizens living in severe poverty, the homeless, long-term unemployed, addicted and socially excluded citizens to offer respective services. Process innovativeness refers to novel production methods, management styles, and technologies that are applied to enhance production and management systems. This type of innovativeness includes the implementation of new management systems such as quality management, redesigning work processes, and introducing project management as a way of operating. Behaviour innovativeness denotes employee and management resourcefulness and interest in new ideas, and organisational encouragement to think and act originally and creatively. This can be seen in initiatives based on stakeholder engagement such as co-creation with stakeholders (e.g. often clients of the organisation) to improve services (Gouillart and Hallett, 2015). A set of behaviour innovativeness demonstrated by front-line employees could be, for example, finding innovative ways to correct problems or responding to customer complaints, which may grow into process innovativeness if instant (yet principle-oriented) reactions are combined into a system. Finally, strategy innovativeness is related to the organisation's capability to achieve goals, identify gaps in goals and resources, react in a timely manner to changes in the market and management's willingness to experiment and search for original approaches to problem solving, showing due appreciation to talented and innovative people. Examples of strategic innovativeness in the public sector include the introduction of green procurement, egovernment systems, crowdsourcing, digitalising archives and partnerships with private companies. Various types of organisational innovativeness may be intertwined. For example, the capability to engage in partnerships may result in co-creation initiatives, a more empathetic attitude to the socially excluded and respective arrangements of tasks and work practices to provide services tailored to their needs. 
Ethical organisational culture can stimulate organisational innovativeness in several ways; for example, by strengthening positive self-evaluation and the self-perception of employees, their identification with their social role and the organisation, fostering open communication, cooperation and productive behaviour. We expand on these interrelations in the following paragraphs.

In general, organisational culture accounts for how individuals internalise organisational values, as it exerts influence on employees through the processes of socialisation, coordination and control (Bandura, 1971; Büschgens et al., 2013). On the other hand, individual values can also have an effect on organisational values through group interactions and the legitimisation of new norms and values (Bandura, 1971; Tajfel, 1982). Social interactions in an organisational context construct group and role identities (Ashforth and Mael, 1989), which, in turn, affect personal identity. Among the numerous identities a person can have, values are the core that creates cohesiveness among them (Hitlin, 2003). If personal and organisational values are congruent, an employee's motivation to identify with a group, department or organisation she works for increases (Ellemers et al., 2013). This is achieved through person-organisation fit, which denotes congruence between the values and norms of individuals and organisations and which affects positive employee outcomes such as job satisfaction or organisational commitment (Chatman, 1989; O’Reilly et al., 1991).

When an organisation sets innovativeness as a goal and pursues it by following ethical values, which are congruent with employees' values, employees can experience positive moral emotions such as respect for and pride in the organisation and oneself because of the achievement and acting in accordance with responsibilities (Malti and Latzko, 2012). For example, a study by Huhtala et al. (2013) demonstrates that an organisational culture which is perceived as ethical directs managers' personal goals to more social and prestige-oriented 
goals, e.g. gaining recognition and appreciation from other members in the organisation and society at large. Experienced positive emotions motivate employees to apply their professional experience and knowledge for the best of the organisation and, thus, engage in creative processes that enhance organisational innovativeness.

Furthermore, congruence of personal and organisational values and positive self-perception account for the willingness in individuals to trust the organisation and its members, and this enhances cooperative behaviour. This context constitutes a favourable basis for communities of practice (Brown and Duguid, 1991) to emerge. Communities of practice are characterised by organisational learning and knowledge sharing (Easterby-Smith et al., 2000), which are essential for the capability to innovate. An ethical organisational culture strengthens the perception for the members of these communities of being safe, recognized, and appreciated for their work and contribution in the organisation, which can affect their creativity, knowledge sharing and ability to work with others and on their own (Park, 2005), leading to the capacity of organisational innovativeness. Hence, we formulate the first hypothesis as follows:

H1: Ethical organisational culture determines organisational innovativeness.

Although prior research on the role of ethical organisational culture in promoting organisational innovativeness both in public and private sectors is scarce, some assumptions on the effect of ethical values on certain types of organisational innovativeness can be drawn. For example, a study by Fernandez and Moldogaziev (2013a; 2013b) provides empirical support to the association between employee empowerment and innovativeness. The researchers conceptualise employee empowerment as a multidimensional construct consisting of four managerial practices such as 1) providing information about goals and performance results, 2) offering rewards based on performance, 3) giving training to ensure job-related 
knowledge and skills, and 4) granting discretion to change work processes. These practices imply ethical virtues, some of them related to the CEV model. For example, the first one would not be possible without clarity, transparency and discussability, the second involves sanctionability, and the third and fourth rest on the virtues of feasibility and supportability. The study focused on frontline employees in public sector organisations and provides arguments that their empowerment affects product, behaviour, and process innovativeness because empowered employees can flexibly and promptly change and improve processes and capture the changing needs of clients. In particular, granting discretion to employees was found to significantly account for the initiation of innovation as it provided the autonomy to act in an innovative way. Hence, it can be assumed that in our study the virtues of clarity, transparency, discussability, feasibility or supportability will influence product, behaviour and process innovativeness.

This assumption is also supported by Brettel et al. (2015). Their study used the Competing Values Framework to study the relationship between organisational culture and innovativeness as a part of the construct of entrepreneurial orientation. Their findings imply that group organisation culture, which is characterised by interpersonal cohesion, mutual trust, inclusion, and loyalty - the values that are represented by supportability, discussability, and transparency in the CEV model - will affect the behaviour and process dimensions of organisational innovativeness.

Prior research on the role of leadership on organisational innovativeness lends support to our assumption that the virtues of congruency of management and supervisors can affect various dimensions of organisational innovativeness. According to Hansen (2011), the bureaucratic and symbolic power that the organisation's management usually possess has a crucial influence on the process of innovation: they can scan the external environment for new ideas 
and bring them to the organisation to consider and decide to adopt them, thus, resulting in new strategic, market and product innovativeness. Moreover, they can encourage employees to be innovative by displaying role model behaviour, fostering a culture of learning and dialogue by giving feedback and asking for advice from specialists, hence, encouraging process and behaviour innovativeness. Empirical research on the interrelations between different virtues of the CEV model and dimensions of organisational innovativeness in Finland has yielded positive results (Riivari et al., 2012; Riivari and Lämsä, 2014). These authors demonstrate that congruency of management affects organisational innovativeness and, in particular, behaviour, process and strategy innovativeness. Therefore, it can be assumed that congruency of management and supervisors may have an effect on a range of types of organisational innovativeness.

On the other hand, as noted by Büschgens et al. (2013), high reliability in organisations such as airlines, hospitals, schools, tax inspections and so on, require stable and consistent processes as well as clearly defined rules and responsibilities to guarantee an environment of safety for the customers and enable its employees to act professionally. As most of these organisations belong to the public sector, it can be assumed that in a public organisation the virtue of clarity will affect process innovativeness but may hinder behaviour innovativeness. Based on the effects of different virtues on the types of organisational innovativeness, we formulate the following hypothesis:

H2: In public organisations, ethical organisational culture will have a stronger impact on process and behaviour innovativeness than on product, strategy or market innovativeness.

The studies by Riivari et al. (2012), and Riivari and Lämsä (2014) have shown that discussability and congruency of management can have an effect on organisational innovativeness, and in particular on process, behaviour and strategy innovativeness. Yet, 
organisational virtues are dependent on a socio-cultural context and the values upheld by a particular society. Therefore, the effect of organisational virtues on innovativeness can also vary in a different socio-cultural context. For example, one of the countries in this study Finland - has a well-developed infrastructure for innovation, including an outstanding education system, which could account for the country's rank at 6 out of 142 countries in the Global Innovation Index 2013 (Cornell University et al., 2013). The other country in this study - Lithuania - has a much weaker infrastructure for innovation development: only in the second decade after it regained its independence in 1990 did businesses and the government start making strategic investments in innovation. As a result, in the Global Innovation Index 2013 Lithuania was ranked 40th (Cornell University et al., 2013). Clearly, the innovation context itself is one of the major differences between the two countries and may determine higher levels of organisational innovativeness in Finland compared to Lithuania.

From the viewpoint of societal values, Finns put strong emphasis on honesty, openness and integrity in private and business life, and society can be described as high-trust both from an institutional and interpersonal viewpoint (Kujala, 2010). These values create a socio-cultural context that appreciates 'diversity, authenticity, tolerance and inclusiveness' (Oliveira and Breda-Vázquez, 2012, p. 523) and, in this way, may facilitate innovativeness development in organisations. Besides, Finland is rather a transparent and corruption-free country, ranking 3rd out of 177 countries in the Corruption Perceptions Index 2013 (Transparency International, 2013). In Lithuania, the rudiments of social networks and blat (Rehn and Taalas 2004), kickbacks to high officials and flattering them with small gifts that were typical of soviet life under continual deficit can still be found in many organisations, in particular, in the public sector. This could explain the country's ranking at 43 in the Corruption Perceptions Index 2013 (Transparency International, 2013). Moreover, due to suppressed individualism, dual norms, and social games during the soviet era (Ryan, 2006; Sztompka, 1999; Ungvari- 
Zrinyi, 2001), to this day employees can still be rather reserved in expressing their true and sincere thoughts and intentions, and lack tolerance of certain social and ethnic groups (Pilinkaitè-Sotirovič and Žibas, 2011; Žiliukaitè et al., 2006), which may inhibit cooperation or eliminate people from organisations with a tendency towards original thought. Hence, weak values of transparency, openness and participation in this socio-cultural context may be problematic in the organisational setting and result in a weak(er) contribution to organisational innovativeness.

Furthermore, the socio-cultural context determines how people are managed in organisations (Kanungo and Jaeger, 1990; Pučètaitè and Lämsa, 2008). For example, employees in Nordic countries such as Finland expect inclusion in decision-making, autonomy and evaluation on the grounds of performance criteria (House et al., 2004). In post-Soviet societies such as Lithuania, employees expect leadership behaviour to demonstrate confidence, decisiveness, assertiveness, and group protective behaviour (House et al., 2004; Pučètaitè and Lämsä, 2008). As the image of the prosecution of citizens that were critical of the state is still fresh people's collective memory, conformism with the leader's opinion may also be outspoken. From the viewpoint of ethical virtues, it can be assumed that discussability, transparency and feasibility will be less practiced in Lithuania than in Finland, and therefore, their effect on organisational innovativeness and its types will be weaker. The importance of the leader in post-Soviet organisations may also mean that congruency of management and supervisors will have a much stronger effect on innovativeness than in Nordic organisations where participative methods are much more practiced. Due to its societal past, when relationships with significant others determined exceptions to the rule or preferential treatment (Ivanauskas, 2011), the virtue of sanctionability may be less practiced in Lithuanian organisations. Therefore, its effect on, for example, behaviour innovativeness that is most strongly related to 
individual innovativeness and, possibly, account for departures from the norms, may be weaker in Lithuanian organisations.

On the other hand, public organisations are usually regulated through extensive legislation and formal rules. Therefore, an ethical virtue such as clarity may be strong and affect innovativeness similarly in Finland and Lithuania. Public sector reforms often introduce process innovations such as quality or environmental management systems, in some cases ethics codes as well; therefore, there is a reason to assume that clarity will be institutionalised through those systems. Hence, we formulate the final hypothesis as follows:

H3: The impact of ethical virtues on the types of organisational innovativeness will be different in Finnish and Lithuanian public organisations.

Figure 1 visualises the dimensions of ethical organisational culture and organisational innovativeness, and depicts the hypothesized relationship between the two constructs. Two types of organisational innovativeness (i.e. process and behaviour) are highlighted as those that may be most affected by CEV.

Insert Figure 1 here

\section{Research setting}

Using a standardized questionnaire, the empirical data were collected from public organisations in Finland $\left(\mathrm{N}_{\mathrm{FI}}=715, \mathrm{n}_{\mathrm{FI}}=477\right.$, a response rate of $\left.67 \%\right)$ in 2011 and Lithuania $\left(\mathrm{N}_{\mathrm{LT}}=1221, \mathrm{n}_{\mathrm{LT}}=757\right.$, a response rate of $\left.62 \%\right)$ in 2013 . At the time of the research the Lithuanian organisation was certified by the quality management standard ISO 9001 and had 
an ethics code. Meanwhile, the Finnish organisation did not have any of these. However, the Finnish organisation had formulated responsibility as one of the principles in its organisational strategy.

The response rates from both organisations were above $50 \%$, which makes the samples representative of the two organisations. The main characteristics of the samples from Finland and Lithuania are presented in Table 1.

Insert Table 1 here

Both samples are dominated by women, $60 \%$ in the Finnish sample and $80 \%$ in the Lithuanian. Most of the respondents in both samples are specialists (over 80\%) and have a higher education with an academic degree $(78 \%$ in the Finnish sample and $92 \%$ in the Lithuanian one). Most respondents in the Finnish and Lithuanian samples are rather familiar with the organisational practices and culture, as the average number of years in the given organisation is respectively 13 and 14 years (std. dev. 10 and 8 years respectively). The age of the respondents was measured differently in the Finnish and Lithuanian samples: the former marked the date of birth, and the latter chose one of the year ranges (e.g. 21-30, 31-40 etc.). The mean of the Finnish respondents' age was 48 (std. dev. 11), and the largest age group $(45 \%)$ in the Lithuanian sample was above 51-years, followed by 41-50 (29\%). Hence, both samples are dominated by middle-aged respondents.

The questionnaire in Finland was available as an e-survey to all employees (Riivari and Lämsä, 2014). The questionnaire in Lithuania was distributed as an e-survey after having 
contacted the top management and posting the link to the communication department for its further dissemination to the employees.

The questionnaire consisted of three thematic scales. Ethical organisational culture was measured using the CEV questionnaire (Kaptein, 2008), which consists of 58 statements encompassing 8 virtues (i.e. clarity, congruency of supervisors, congruency of management, feasibility, supportability, transparency, discussability, and sanctionability). The items were evaluated using Likert scale from 1 to 6, 1 denoting "strongly disagree" and 6 "strongly agree". Organisational innovativeness was measured using the 20-item questionnaire by Wang and Ahmed (2004), which consists of 5 thematic blocks related to product, market, behaviour, process and strategy innovativeness. A 7-point Likert scale was used with 1 meaning "strongly disagree" and 7 "strongly agree". Participants in the Lithuanian sample could also select "I do not know" as their answer; this was coded as missing data and eliminated from further analysis. This, in part, explains the smaller sample of answers in the Lithuanian study. Some items were originally negatively worded and were reversed for analysis in the overall data. The third block of questions included the background characteristics of the respondents.

Statistical analysis of the data was accomplished using the SPSS 22.0 software for Windows. The data were analysed in two samples (i.e. Finnish and Lithuanian) and two groups of variables: a group consisting of five variables measuring different types (i.e. product, market, strategy, process, and behaviour) of $\mathrm{ON}$, and the other group consisting of eight variables measuring ethical organisational culture or CEV (for detailed descriptions of this set of variables see Kaptein, 2008; Riivari and Lämsä, 2014; Riivari et al., 2012). We used two samples instead of one as the organisations represented two different societies and their cultures could be considerably different. Therefore, using one sample to test the research 
framework would not have allowed to make proper statistical generalisation. Another advantage of using two samples rather than one for statistical analysis allowed us to make interpretations how socio-cultural contexts affect two organisations which are similar from the viewpoints of work content and structures but may practice different values and therefore have two different characters (i.e. cultures), which is suggested by the virtue theory. Besides, when developing hypothesis 3 we argued that the relationships between particular virtues and types of organisational innovativeness are different and did not question how socio-cultural background (e.g. nationality) of the respondents will affect the relationships in focus.

The data were analysed in several steps. First, for an initial exploratory comparison of the Finnish and Lithuanian samples, descriptive characteristics were calculated (i.e. min and max values, mean, std. deviation). At this point, a short comment about some differences of the Finnish data analysed in this paper and the one published in the Journal of Business Ethics (Riivari and Lämsä, 2014) has to be made. In the mentioned paper, the variables of discussability and sanctionability were calculated as averages, which were arithmetically rounded for the statistical analysis. In this paper, the exact data are used in the analysis, which explains the differences in the descriptive indicators and the results of the regression analysis.

Second, ordinary partial correlations (Pearson's r coefficients) between different types of CEV and ON were calculated for the Finnish and Lithuanian samples with gender as a control variable. Gender was controlled for, as prior research indicates that women are more sensitive to ethical dimensions in social phenomena and problem-solving (Donoho et al., 2012). Third, the effects of the virtues of $\mathrm{CEV}$ on different forms of organisational innovativeness were tested using a series of linear regressions (stepwise method). Based on that, different interpretative models were developed with a range from 1 to 4 . The paper discusses the models with the highest explanatory power $\left(\operatorname{adj} . \mathrm{R}^{2}\right)$. 


\section{Findings}

The findings of the descriptive data analysis are presented in Table 2. Cronbach's alphas for $\mathrm{CEV}$ and $\mathrm{ON}$ as multidimensional variables in the Finnish and Lithuanian samples are, respectively, 0.97 and $0.98(\mathrm{CEV})$ and 0.86 and $0.90(\mathrm{ON})$, which suggests high reliability and internal consistency of the scales in both samples. The means of the respondents' evaluations for the CEV and $\mathrm{ON}$ in the Finnish organisation are 4.3 and 3.9 respectively (std. dev. 0.634 and 0.702 respectively). The mean of CEV in the Lithuanian sample is almost the same, 4.5 (std. dev. 0.827), and the mean of ON is higher by 1 point, 4.9 (std. dev. 0.927). The results of the independent samples T-test reveal that the average evaluations of all CEV and ON dimensions are statistically significantly different in the Finnish and Lithuanian samples.

From the overall perspective, the Lithuanian respondents evaluated dimensions of both CEV and ON higher than the Finnish ones except for the virtue of feasibility, which was almost the same in both organisations. A greater difference was found in the means of market innovativeness and strategy innovativeness, which were higher by 1.5 and 1 point respectively in the Lithuanian organisation.

Insert Table 2 here

At this point, the number of responses to the survey questions in the Lithuanian sample should be commented upon. The largest number of missing answers is in the evaluations of organisational innovativeness: more than half of the respondents avoided a definite answer in 
respect to strategy innovativeness. The behaviour dimension, which had the least number of missing categories, was not evaluated by more than $30 \%$ of the respondents. The dimensions from the CEV model, which were not evaluated by more than half of the respondents, were transparency and sanctionability. The results indicate that the respondents either avoided a direct answer or simply did not have enough knowledge of organisational practices related to CEV or ON. This could explain a significantly higher mean in the evaluations of strategy innovativeness in the Lithuanian sample: presumably, those who answered had more knowledge about organisational practices related to strategy. However, the factual response rate to the definite variables does not explain other differences but is rather indicative of the extent of the respondents' knowledge or reflection on certain value-laden organisational practices.

In the Finnish sample, the virtues that score highest are clarity (mean 4.9, std. dev. 0.652), congruency of supervisors and feasibility (means 4.8, respective std. dev. 0.918 and 0.782 ). In the Lithuanian sample, as in the Finnish sample, clarity and congruency of supervisors (mean 5.2, respective std. dev. 0.839 and 1.091) score highest, closely followed by congruency of management (mean 5.1, std. dev. 1.123). Hence, at perception level, the self-correcting capacity of an organisation is most missing in both organisations. From the perspective of $\mathrm{ON}$, process innovativeness is among the dimensions that score the highest in both Finnish and Lithuanian organisations (respectively, means 4.5 and 5.0, std. dev. 0.904 and 1.211). Product innovativeness has the second highest mean in the Finnish (4.3, std. dev. 0.704) and the third in the Lithuanian sample (4.9, std. dev. 0.936). The results of the paired samples Ttest demonstrate that only the average evaluation of product and behaviour dimensions of ON in both samples have no statistically significant difference. In the case of CEV, most dimensions were evaluated as statistically significantly different in both samples. However, in the Finnish sample, there is no difference between the average evaluations of congruency of 
supervisors and feasibility, supportability and transparency; in the Lithuanian sample, congruency of supervisors and clarity, feasibility and supportability, feasibility and discussability, feasibility and sanctionability, transparency and sanctionability received the same average evaluations $(\mathrm{p}>0.05)$.

The partial correlation analysis with gender as a control variable yielded statistically significant positive results among all types of $\mathrm{CEV}$ and $\mathrm{ON}$ in both the Finnish and the Lithuanian samples (Table 3), except for the interrelations between the following pairs: market innovativeness on the one hand and congruency of supervisors and feasibility on the other hand, product innovativeness - feasibility in the Finnish sample and product, market and behaviour innovativeness on the one hand, and feasibility on the other hand in the Lithuanian sample. As indicated by the numbers, perceptions of the interrelations between the types of organisational innovativeness and the virtue of feasibility are least affected by gender.

Insert Table 3 here

The regression analysis between $\mathrm{CEV}$ and $\mathrm{ON}$ as multidimensional variables yielded statistically significant results, which support $\mathrm{H} 1$. The adjusted $\mathrm{R}^{2}$ in the analysed relationship is higher in the Lithuanian sample than in the Finnish one, respectively, 0.4 and $0.3(p<0.01, \beta$ coefficients 0.629 and 0.544 ), suggesting that CEV has more explanatory power for $\mathrm{ON}$ in the Lithuanian organisation. 
Considering the effect of different values on $\mathrm{ON}$ as a multi-dimensional variable, the triad of congruency of management, sanctionability and transparency explain $32 \%$ of ON (Table 4) in the Finnish sample, and the four virtues of congruency of management, clarity, congruency of supervisors and supportability explain $49 \%$ of ON in the Lithuanian sample. Notably, however, coefficient beta between congruency of supervisors and $\mathrm{ON}$ in the given sample is negative, which indicates that the supervisor's behaviour may diminish organisational innovativeness. The same effect can be observed in the relationship between feasibility and behaviour innovativeness, i.e. the beta coefficient is negative there as well $(-0.13, p<0.05)$. These findings indicate a different set of organisational capacities that impact upon ON in the Finnish and Lithuanian organisations. In the Finnish sample, the virtues that affect ON represent self-regulating and self-correcting capacities, and in the Lithuanian sample, the explanatory virtues are primarily related to the capacity to self-regulate.

Insert Table 4 here

Further regression analysis between different types of $\mathrm{ON}$ as dependent variables and virtues of the $\mathrm{CEV}$ model as determinants demonstrates that process and behaviour innovativeness are most strongly affected by ethical virtues both in the Finnish and the Lithuanian samples (respectively, adj. $\mathrm{R}_{\text {FIN }}^{2} 0.33$ and 0.37 and adj. $\mathrm{R}_{\mathrm{LT}}^{2} 0.34$ and $0.42, \mathrm{p}<0.001$ ). Ethical virtues have almost no effect on product and market innovativeness in the Finnish sample (respectively, adj. $\mathrm{R}^{2} 0.07$ and $0.04, \mathrm{p}<0.001$ ), but do affect them in the Lithuanian sample (respectively, adj. $\mathrm{R}^{2} 0.24$ and $0.23, \mathrm{p}<0.001$ ). However, the effect on these types of $\mathrm{ON}$ is weaker compared to the effect of CEV on process and behaviour innovativeness. These findings support H2. 
Considering the effect of ethical virtues on certain types of innovativeness, some virtues repeatedly occur in several models, yet their combination with other virtues differs. For example, in the Finnish sample, the virtue of congruency of management has an influence on process, behaviour and strategy innovativeness; transparency, on product, market and strategy innovativeness; discussability, on process and behaviour innovativeness; and clarity, on product and process innovativeness. In the Lithuanian sample, clarity affects all types of innovativeness except behaviour; discussability affects product, process and behaviour; congruency of management affects behaviour and strategy; and supportability affects market and behaviour innovativeness. The discussed impact of ethical virtues on the types of $\mathrm{ON}$ are illustrated in Figure 2.

\section{Insert Figure 2 here}

In general, the ethical virtues that impact on different types of $\mathrm{ON}$ vary between the two countries. For example, behaviour innovativeness in the Finnish sample is affected by sanctionability, congruency of management, discussability and congruency of supervisors (respectively, betas $0.19, \mathrm{p}<0.01 ; 0.21, \mathrm{p}<0.001 ; 0.19, \mathrm{p}<0.01$ and $0.11, \mathrm{p}<0.05$ ), while by congruency of management, discussability, supportability and feasibility (respectively, betas $0.29, \mathrm{p}<0.001 ; 0.20, \mathrm{p}<0.5 ; 0.26, \mathrm{p}<0.01$ and $-0.13, \mathrm{p}<0.05)$ in the Lithuanian sample. Although two ethical virtues are identical, their weight is different. In the Finnish sample, employee behaviour is regulated by the knowledge of sanctions for improper behaviour, which implies that the systems in the organisation are built on fairness and justice. In the 
Lithuanian sample, organisational capability to engage in creative processes is affected by the

role models and examples set by the management. Process innovativeness is affected by discussability and clarity in both samples, yet in addition, congruency of management plays a role in the Finnish sample. Congruency of management matters in strategy innovativeness in both samples, yet its effect is the strongest in combination with transparency in the Finnish, and clarity and feasibility in the Lithuanian sample. These results lend support for H3.

\section{Discussion and conclusions}

In this study we explored the interrelations among dimensions of ethical organisational culture and organisational innovativeness in two public organisations operating in two socioculturally different contexts, i.e. Finland and Lithuania. Our findings supported all three hypotheses: ethical organisational culture has an effect on organisational innovativeness, process and behaviour innovativeness are most strongly affected by ethical organisational culture, and ethical virtues influencing organisational innovativeness to some extent vary in Finnish and Lithuanian public organisations.

In this respect, our study lends cross-cultural support to the research in Finland on the impact of ethical organisational culture on organisational innovativeness (Riivari and Lämsä, 2014; Riivari et al., 2012). Moreover, it indicates the crucial importance of congruency of management, discussability and clarity for enhancing a public organisation's capability to innovate, in particular, at behaviour and process levels in both socio-cultural contexts. In particular, this result is important with respect to the virtue of clarity that implies the presence of documented rules or detailed procedures, which can be a hindrance to organisational creativity as suggested by Amabile et al. (1996). Yet, in the public sector, clarity induces innovativeness through the knowledge of ethical principles and values, which one expects to be followed by all employees of a particular organisation or even sector. Hence, clarity 
creates the basis for creativity and improvising in an ethically secure environment and ensures the individual's autonomy to practice her expertise, providing high-quality services to citizens at the same time. This finding is in line with suggestions made by Fernandez and Moldogaziev (2013a; 2013b) and points out the need for clearly defined rules and consistent reliance on them in a public sector organisation. Therefore, our study contributes to the academic discourse on the effectiveness of codes of ethics (Kaptein and Schwartz, 2008), indicating that they serve as an instrument for ensuring security (Vasiljeviene, 2000), selfregulation (Cavanagh, 2004) and stimulating the capability to innovate. Admittedly, in the long run, the problem of over-bureaucratization may arise; therefore, reflection of rules, procedures and processes from the perspective of their functionality should be a regular practice in organisations that are committed to high quality public service.

In addition, the findings provide evidence that opportunities to discuss ethical issues provided by ethics management tools such as ethics training can also enhance organisational innovativeness. Becoming familiar with co-employees' moral attitudes and questioning one's own beliefs and behaviour from an ethical perspective facilitates the process of becoming 'moral acquaintances', which is a pre-requisite for trust development (Lämsä and Pučètaitè, 2006). Consequently, trust enhances the chances of knowledge sharing and cooperation, which is essential to organisational capability to innovate. Finally, the integrity of managers and their support for ethics management systems also strengthens organisational innovativeness by creating consistency and security for the employees, who open up their potential for creativity in regard to organisational goals. If these goals are compatible with the common good, ethical virtues may be helpful in ensuring a culture that fosters innovativeness and overcomes the risk that creative employees may tend to innovate disregarding the common good as noted by Gino and Ariely (2011). In this respect, an ethical organisational culture has the potential to become a factor for responsible innovativeness and innovations. 
The latter academic discourse is comparatively new but scholars in this field highlight economic, social and environmental impacts of innovation as a process and an outcome (Blok and Lemmens, 2015; Halme and Korpela, 2014). Thus, ethical organisational culture is a set of collective characteristics that ensures responsible processes for innovative outcomes which promote the common good.

Considering the ethical virtues that determined organisational innovativeness and its particular types, we have to acknowledge that some findings opposed our initial assumptions. For example, we expected that congruency of management would be a much more important virtue in the post-Soviet (i.e. Lithuanian) context, and democratic values such as discussability would be more important in the Nordic context. Our findings indicated that these virtues are important in both contexts, suggesting that the effect of clarity, discussability and congruency of management on organisational innovativeness may be determined by the institutional rather than the socio-cultural context.

Another characteristic that is typical of both studied organisations is the considerably weak effect of ethical organisational culture on product and market innovativeness in the public sector. This can be explained by the fact that products or services in public organisations are highly standardized and routinized; therefore, innovative processes or individual actions when providing services are the only fields where innovativeness can be manifested. Moreover, most large public organisations globally are rather hierarchical, and hierarchical structures and cultures were found to inhibit product innovativeness (Valencia et al., 2010). Besides, there are usually no or very few competitors for certain public sector organisations, despite global efforts to decentralize and privatize the public sector. In this case, the low dependence of market innovativeness on ethical organisational culture could be explained by the lack of marketing programmes in the organisation. Strategy innovativeness may also be little affected 
by organisational-level factors if the strategy for a public organisation is formulated by the government.

On the other hand, the study highlights differences in the importance of ethical virtues for organisational innovativeness. For example, transparency and sanctionability were established as determinants of several types of organisational innovativeness in the Finnish organisation while these did not play any role in the Lithuanian organisation. The importance of sanctionability, which emerged as a result of the regression analysis in the Finnish organisation, implies that the employees' capacity to think and act creatively, for example, in problem solving, or to engage in new activities, is encouraged by the knowledge that ethically proper behaviour will be rewarded and improper punished. A perception of justice ensures safety and security in the organisation and may incite benevolence to reciprocate the organisation, for example, by sharing tacit knowledge and applying one's skills to the benefit of the organisation.

The results from a post-Soviet society organisation imply the importance of relational aspects in fostering organisational innovativeness. For example, supportability is exceptionally active in respect to innovativeness in the Lithuanian organisation and has no effect in the Finnish organisation. In particular, behaviour innovativeness is motivated by collegial support, trust, and relationship quality, which may also be an indication of groupthink. Therefore, considering the society's past, this dependence raises organisational risks that exceptions to rules or regulations could be made if people in decision-making positions start abusing their power and engaging in "cover-up" behaviour with their supervisors or colleagues relying on relationships with them. This risk is diminished by well-perceived virtues constituting capacity for self-regulating; however, the lack of sanctionability and transparency in the 
culture may account for cases of harmful innovativeness that undermines public trust in institutions.

Moreover, in the Lithuanian organisation congruency of supervisors and feasibility had negative impact on organisational innovativeness. These results have strong socio-cultural implications. First, the negative impact of congruency of supervisors could be a result of socialisation in a post-Soviet context. For a long time, the leader was considered responsible and accountable for all outcomes in organisations. Even when more participative principles and team-working practices were introduced in Lithuanian organisations after the shift from the planned to market economy, employees tended to comply with the leader's opinions and suggestions (Seilius, 1999). Hence, considering the age of the respondents and the socialisation time in the given organisation it can be assumed that in this public sector organisation employees tend to ascribe themselves a role of task performers rather than ideagenerators if the supervisor is innovation-oriented. On the other hand, congruency of supervisors in public organisations operating in the post-Soviet context often manifests through compliance with the letter rather than the spirit of the law because of the low level of trust in the society. Compliance with rules may be understood as a guarantee of legitimacy and accountability of decisions and risk management, undermining the negative (possibly, unintended) consequences of discretion. However, too rigid a compliance with the rules and procedures may also undermine organisational innovativeness. This aspect explains positive effect of congruency of supervisors in the Finnish organisation as it operates in a high-trust societal context which gives more freedom to practise discretion (cf. MacCarthaigh, 2011). In such societies, citizens believe that public servants and institutions will rely on ethical principles and professional norms and congruency of supervisors may be perceived as compliance with principles rather than rules. 
The negative effect of feasibility on behaviour innovativeness could be explained by a psychological effect. Although employee empowerment with resources is important to innovation development, in some cases sufficiency of resources may act against innovativeness as the comfort zone is large enough and there are no motivators to induce changes in the "usual" attitudes and behaviour which produce break-through results (Gibbert et al., 2007). Hence, as many public organisations in new democracies have to deal with the scarcity of resources, this constraint may act positively on the skills of individuals to cope with their job tasks and result in employing innovative problem-solving methods as suggested by Gintner et al. (1989). Considering the ethical issues present in this socio-cultural context, the management in these organisations have to implement proper monitoring practices and strengthen the virtues of clarity and discussability to ensure that the organisation not only serves individual clients or solves urgent problems but also promotes the common good. In this way, it would diminish the possibility of unethical innovative behaviour that is characteristic of creative employees (cf. Gino and Ariely, 2011).

Our study has some limitations. As anonymity and confidentiality was promised to the organisations, a deeper analysis of other contextual factors affecting organisational innovativeness in particular organisations (e.g. in the form of a case study) was not possible. Therefore, we acknowledge that the findings obtained from the two organisations are not generalizable to all public sector organisations. To increase our knowledge about the effects of ethical organisational culture on organisational innovativeness, a sample should be increased to include more public organisations from each country or/and the results have to be compared to data from the private sector. It is very likely that the virtues and their effect on innovativeness will differ. Findings from a considerably different socio-cultural context or from other organisations in Nordic and post-Soviet societies could also provide data for more generalizable conclusions. Using mixed methods (Riivari, 2015), i.e. carrying out a 
quantitative study with qualitative methods such as interviews with managers of organisations, document analysis or participant observation, could also contribute to more generalisable results.

\section{Acknowledgement}

The research in Lithuania was funded by the European Social Fund under the Global Grant measure (project No. VP1-3.1-ŠMM-07-K-03-042).

\section{References}

1. Alvesson, M. (2011). Organizational culture: Meaning, discourse, identity. In N. Ashkanasy, C. P. M. Wilderom and Peterson, M. F. (eds.), The handbook of organizational culture and climate, 2nd edition, (pp. 11-28). Sage Publications, Los Angeles, London etc.

2. Amabile, T.M., Conti, R., Coon, H., Lazenby, J. and Herron, M. (1996). Assessing the work environment for creativity. Academy of Management Journal 39(5), 1154-1184.

3. Ashforth, B.E. and Mael, F. (1989). Social identity theory and the organization. Academy of Management Review 14(1), 20-39.

4. Bandura, A. (1971). Social learning theory. General Learning Press, New York, NY.

5. Baucus, M.S., Norton, W.I., Baucus, D.A. and Human, S.H. (2008). Fostering creativity and innovation without encouraging unethical behavior. Journal of Business Ethics 81(1), 97-115.

6. Bauman, D.C. (2013). Leadership and the three faces of integrity. The Leadership Quarterly 24, 414-426.

7. Blok, V. and Lemmens, P. (2015). The emerging concept of responsible innovation. Three reasons why it is questionable and calls for a radical transformation of the concept of innovation. In B.-J. Koops, J. van den Hoven, H. Romijn, T. Swierstra and Oosterlaken, I. Responsible Innovation 2: Concepts, Approaches and Applications (pp. 19-35). Springer, Dordrecht.

8. Brettel, M., Chomik, C. and Flatten, C. (2015). How organizational culture influences innovativeness, proactiveness, and risk-taking: fostering entrepreneurial orientation in SMEs. Journal of Small Business Management 53(4), 868-885. 
9. Broekel, T. and Brenner, T. (2011). Regional factors and innovativeness: an empirical analysis of four German industries. Annals of Regional Science 47, 169-194.

10. Brown, J.S. and Duguid, P. (1991). Organizational learning and communities of practice: Toward a unified view of working, learning and innovation. Organization Science 2(1), 40-57.

11. Büschgens, T., Bausch, A. and Balkin, D.B. (2013). Organizational culture and innovation: a meta-analytic review. Journal of Product Innovation Management 30(4), $763-781$

12. Cavanagh, G.F. (2004). Global business ethics: regulation, code, or self-restraint. Business Ethics Quarterly 14(4), 625-642.

13. Chatman, J. (1989). Improving interactional organisational research: A model of person-organization fit. Academy of Management Review 14(1), 333-349.

14. Cho, H.-J. and Pucik, V. (2005). Relationship between innovativeness, quality, growth, profitability, and market value. Strategic Management Journal 26, 555-575.

15. Cornell University, INSEAD and WIPO (2013). The Global Innovation Index 2013: The Local Dynamics of Innovation. Geneva, Ithaca, and Fontainebleau.

16. Donoho, C., Heinze, T. and Kondo, C. (2012). Gender differences in personal selling ethics evaluations: Do they exist and what does their existence mean for teaching sales ethics? Journal of Marketing Education 34(1), 55-66.

17. Easterby-Smith, M., Crossan, M., Nicolini, D. (2000). Organizational learning: Debates past, present and future. Journal of Management Studies 37 (6): 783-796.

18. Ellemers, N., Sleebos, E., Stam, D. and de Gilder, D. (2013). Feeling included and valued: How perceived respect affects positive team identity and willingness to invest in the team. British Journal of Management 24, 21-37.

19. Ellonen, R., Blomqvist K. and Puumalainen, K. (2008). The role of trust in organisational innovativeness. European Journal of Innovation 11(2), 160-181.

20. Fernandez, S. and Moldogaziev, T. (2013a). Employee empowerment, employee attitudes, and performance: Testing a causal model. Public Administration Management 73(3), 490-506.

21. Fernandez, S. and Moldogaziev, T. (2013b). Using employee empowerment to encourage innovative behavior in the public sector. Journal of Public Administration Research and Theory 23, 155-187.

22. Gibbert, M., Hoegl, M. and Välikangas, L. (2007). In praise of resource constraints. MIT Sloan Management Review 48(3), 15-17. 
23. Gino, F. and Ariely, D. (2011). The dark side of creativity: Original thinkers can be more dishonest. Journal of Personality and Social Psychology 102 (3), 445-459.

24. Gintner, G. G., West, J. D., \& Zarski, J. J. (1989). Learned resourcefulness and situation specific coping with stress. Journal of Psychology, 123(3), 295-304.

25. Gouillart, F. and Hallett, T. (2015). Co-creation in government. Stanford Social Innovation Review, Spring 2015, 40-47.

26. Halme M. and Korpela M. (2014). Responsible innovation toward sustainable development in small and medium-sized enterprises: A resource perspective. Business Strategy and the Environment 23, 547-566, doi: 10.1002/bse.1801

27. Hansen, M.B. (2011). Antecedents of organizational innovation: The diffusion of new public management into Danish local government. Public Administration 89(2), 285306.

28. Helkama, K. and Seppälä, T. (2006). Arvojen muutos Suomessa 1980-2000 [Value change in Finland 1980-2000]. In R. Heiskala and E. Raekallio (eds.), Uusi jako: Kuinka Suomesta tuli kilpailukykyinen yhteiskunta [The new division: How Finland became a competitive society], (pp. 131-155). Gaudeamus, Helsinki.

29. Hitlin, S. (2003). Values as the core of personal identity: Drawing links between two theories of self. Social Psychology Quarterly 66(2), 118-137.

30. Hlepas, N. (2013). Quality of life and local governance. SEARCH Working paper WP5/21, available at $\quad<$ http://www.ub.edu/searchproject/wpcontent/uploads/2013/09/WP05.21.pdf>, accessed on August 6, 2014.

31. Hood, C. (1991). A public management for all seasons. Public Administration 69(1), 3-19.

32. House, R.J., Hanges, P.J., Javidan, M., Dorfman, P.W. and Gupta, V. (eds.) (2004). Culture, leadership, and organizations: The GLOBE study of 62 societies. Sage Publications, Thousand Oaks.

33. Huhtala, M., Feldt, T., Hyvönen, K. and Mauno, S. (2013). Ethical organizational culture as a context for managers' personal work goals. Journal of Business Ethics $114,265-282$.

34. Hurley, R.F. and Hult, T.G.R. (1998). Innovation, market orientation, and organizational learning: an integration and empirical examination. Journal of Marketing 62, 42-54.

35. Ivanauskas, V. (2011). Lietuviškoji nomenklatūra biurokratinejje sistemoje: Tarp stagnacijos ir dinamikos (1968-1988) [Lithuanian nomenclature in bureaucratic 
system: Between stagnation and dynamics (1968-1988)]. Lietuvos istorijos instituto leidykla, Vilnius.

36. Jordan, S.R. The innovation imperative: An analysis of the ethics of the imperative to innovate in public sector service delivery. Public Management Review 16(1), 67-89.

37. Kanungo, R.N. and Jaeger, A.M. (1990). Introduction: The need for indigenous management in developing countries. In A.M. Jaeger and Kanungo, R.N. (eds.), Management in developing countries, (pp. 1-23). Routledge, London.

38. Kaptein, M. (2008). Developing and testing a measure for the ethical culture of organizations: the corporate ethics virtue model. Journal of Organisational Behaviour 29, 923-947.

39. Kaptein, M. (2010). The ethics of organizations: a longitudinal study of the U.S. working population. Journal of Business Ethics, 92(4), 601-618.

40. Kaptein, M. and Schwartz, M.S. (2008). The effectiveness of business codes: a critical examination of existing studies and the development of an integrated research model. Journal of Business Ethics 77, 111-127.

41. Keith, N. and Frese, M. (2011). Enhancing form performance and innovativeness through error management culture. In N.M. Ashkanasy, C.P.M. Wilderom and M.F. Peterson (eds.), The handbook of organizational culture and climate, 2nd edition, (pp. 137-157). Sage, Los Angeles, London etc.

42. Kujala, J. (2004). Managers' moral perceptions: change in Finland during the 1990s. Business Ethics: A European Review 13(2/3), 143-165.

43. Kujala, J. (2010). Corporate responsibility perceptions in change: Finnish managers' views on stakeholder issues from 1994 to 2004. Business Ethics: European Review 19(1): 14-34.

44. Kuokštis, V. (2012). Trust and taxes: Estonian and Lithuanian fiscal performance during the crisis, APSA 2012 Annual Meeting Paper, available at $<\mathrm{http}: / /$ ssrn.com/abstract=2104562>, accessed on June 2, 2014.

45. Lämsä, A.-M. and Pučètaitè, R. (2006). Development of organizational trust among employees from a contextual perspective. Business Ethics: a European Review 15(2): 130-141.

46. Lämsä, A.-M. and Viljanen, S. (2014). Finland: Positive union engagement with CSR. In L. Preuss, M. Gold and Rees, C. (eds.), Corporate social responsibility and trade unions: Perspectives across Europe. Routledge, in press. 
47. Lumpkin, G.T. and Dess, G.G. (1996). Clarifying the entrepreneurial orientation construct and linking it to performance. Academy of Management Review 21, 135172.

48. MacCarthaigh, M. (2011). Discretion. In B. Baddie, D. Berg-Schlosser and Morlino, L. International Encyclopedia of Political Science (pp. 677-679). Sage Publications, Thousand Oaks.

49. MacLean, T., Litzky, B. E., and Holderness Jr, D. K. (2015). When organizations don't walk their talk: A cross-level examination of how decoupling formal ethics programs affects organizational members. Journal of Business Ethics 128, 351-368.

50. Malti, T. and Latzko, B. (2012). Moral emotions. In V. Ramachadran (ed.), Encyclopedia of Human Behaviour, 2nd edition, (pp. 644-649). Elsevier, Maryland Heights.

51. Martins, E. and Martins, N. (2002). An organizational culture model to promote creativity and innovation. Journal of Industrial Psychology 28(4), 58-65.

52. Martins, E.C. and Terblanche, F. (2003). Building organizational culture that stimulates creativity and innovation. European Journal of Innovation Management 6(1), 64-74.

53. Mayer, R., Davis, J. and Schoorman, D. (1995). An integrative model of organizational trust. Academy of Management Review 20, 709-734.

54. Morgan, E. (1998). Navigating cross-cultural ethics: What global managers do right to keep from going wrong. Butterworth-Heinemann, Woburn, USA.

55. Mumford, M.D. (2000). Managing creative people: strategies and tactics for innovation. Human Resource Management Review 10(3), 313-351.

56. O’Reilly III, C., Chatman, J., Caldwell, D. F. (1991). People and organizational culture: a profile comparison approach to assessing person-organization fit. Academy of Management Journal 34(3), 487-516.

57. Oinas, P. (2005). Finland: A success story? European Planning Studies 13(8), $1227-1244$.

58. Oliveira, C. and Breda-Vázquez, I. (2012). Creativity and social innovation: what can urban policies learn from sectoral experiences? International Journal of Urban and Regional Research 36(3), 522-538.

59. Park, J. (2005). Fostering creativity and productivity through emotional literacy: The organizational context. Development and Learning in Organizations 19(4), 5-7. 
60. Pilinkaitè-Sotirovič, V. and Žibas, K. (2011). Etninès ir socialinès grupès Lietuvoje: visuomenès nuostatos ir jų kaita [Ethnic and social groups in Lithuania: Societal attitudes and their changes]. Etninès studijos 1-2, 136-155.

61. Politt, C. and Bouckaert, G. (2011). Public management reform: A comparative analysis, 3rd edition. Oxford University Press, Oxford.

62. Prajogo, D. I. and McDermott, C.M. (2011). The relationship between multidimensional organizational culture and performance. International Journal of Operations \& Production Management 31(7), 712-735.

63. Pučètaitè, R. and Lämsä, A.-M. (2008). Developing organizational trust through advancement of employees' work ethics in a post-socialist context. Journal of Business Ethics 82, 325-337.

64. Pučètaitè, R., Lämsä, A.-M. and Novelskaitè, A. (2010). Organizations which have the strongest potential for high-level organizational trust in a low-trust societal context. Transformations in Business and Economics 9(2), 318-334.

65. Quinn, R.E. and Spreitzer, G.M. (1991). The psychometrics of the competing values culture instrument and an analysis of the impact of organizational culture on quality of life. Research in Organizational Change and Development 5, 15-42.

66. Rehn, A. and Taalas, S. (2004). "Znakomstva i svyazi" (Acquaintances and connections) - Blat, the Soviet Union, and mundane entrepreneurship. Entrepreneurship \& Regional Development 16, 235-250.

67. Riivari, E. (2015). Mixing methods in organizational ethics and organizational innovativeness research: Three approaches to mixed methods analysis. In Pučetaitè, R., Novelskaitè, A. and Pušinaitè, R. (eds.) Organizacijų etika, novatoriškumas ir darniosios inovacijos [Organisational ethics, innovativeness and sustainable innovations], (pp. 193-207). Academic publishing, Vilnius.

68. Riivari, E., and Lämsä, A. M. (2014). Does it pay to be ethical? Examining the relationship between organisations' ethical culture and innovativeness. Journal of Business Ethics, 124(1), 1-17.

69. Riivari, E., Lämsä, A.-M., Kujala, J. and Heiskanen, E. (2012). The ethical culture of organisations and organisational innovativeness. European Journal of Innovation Management 15(3), 310-331.

70. Ryan, L.V. (2006). Current ethical issues in Polish HRM. Journal of Business Ethics 66, 273-290. 
71. Sankowska, A. (2013). Relationships between organizational trust, knowledge transfer, knowledge creation, and firm's innovativeness. Learning Organization 20(1), $85-100$.

72. Sarros, J.C., Cooper, B.K. and Santora, J.C. (2008). Building a climate for innovation through transformational leadership and organizational culture. Journal of Leadership and Organizational Studies 15(2), 145-158.

73. Schein, E.H. (1990). Organizational culture. American Psychologist 45(2), 109-119.

74. Seilius, A. (1999). Kolektyvinis valdymas: teorija ir praktika [Collective management: theory and practice]. Organizacijų vadyba: sisteminiai tyrimai 12, 189-211.

75. Solomon, R.C. (2004). Aristotle, ethics and business organizations. Organization Studies 25, 1021-1043.

76. Sztompka, P. (1999). Trust: A sociological theory. Cambridge University Press, Cambridge.

77. Tajeddini, K., Trueman, M. and Larsen, G. (2006). Examining the effect of market orientation on innovativeness. Journal of Marketing Management 22 (5-6), 529-551.

78. Tajfel, H. (1982). Social psychology of intergroup relations. Annual Review of Psychology 33, 1-39.

79. Transparency International. (2013). Corruption perception index 2013. Berlin. Available at <http://cpi.transparency.org/cpi2013/results/\#myAnchor2>, accessed on June 2, 2014.

80. Trevinõ, L.K., Butterfield, K.D. and McCabe, D.L. (1998). The ethical context in organizations: Influences on employee attitudes and behaviors. Business Ethics Quarterly 8 (3), 447-476.

81. Ungvari-Zrinyi, I. (2001). Moralinès kultūros tendencijos postkomunistinèse visuomenèse [Moral culture in post-communist countries]. In N. Vasiljevienè (ed.), Dalykinė etika [Business ethics], (pp. 229-247). Vilnius University, Kaunas.

82. Valencia, J.C.N., Valle, R.S. and Jiménez, D.J. (2010). Organizational culture as determinant of product innovation. European Journal of Innovation Management 13(4), 466-480.

83. Vasiljevienè, N. (2000). Verslo etika ir elgesio kodeksai [Business ethics and codes of conduct]. VU KHF, Kaunas.

84. Wang, C. L. and Ahmed, P. K. (2004). The development and validation of the organizational innovativeness construct using confirmatory factor analysis. European Journal of Innovation Management 7, 303-313. 
85. Wieland, J. (2003). ValuesManagementSystemZfW: A new standard for values driven management. In J. Wieland, (ed.) Standards and audits for ethics management systems: The European perspective, (pp. 3-23). Springer, Berlin.

86. Yu, Y., Dong, X.-Y., Shen, K.N., Khalifa, M. and Hao, J.-X. (2013). Strategies, technologies, and organizational learning for developing organizational innovativeness in emerging economies. Journal of Business Research 66, 2507-2514.

87. Žiliukaitè, R., Ramonaitè, A., Nevinskaitè, L., Beresnevičiūtè V. and Vinogradnaitè I. (2006). Neatrasta galia: Lietuvos pilietinès visuomenès žemėlapis [Undiscovered power: Map of the Civil Society in Lithuania]. Versus Aureus, Vilnius. 


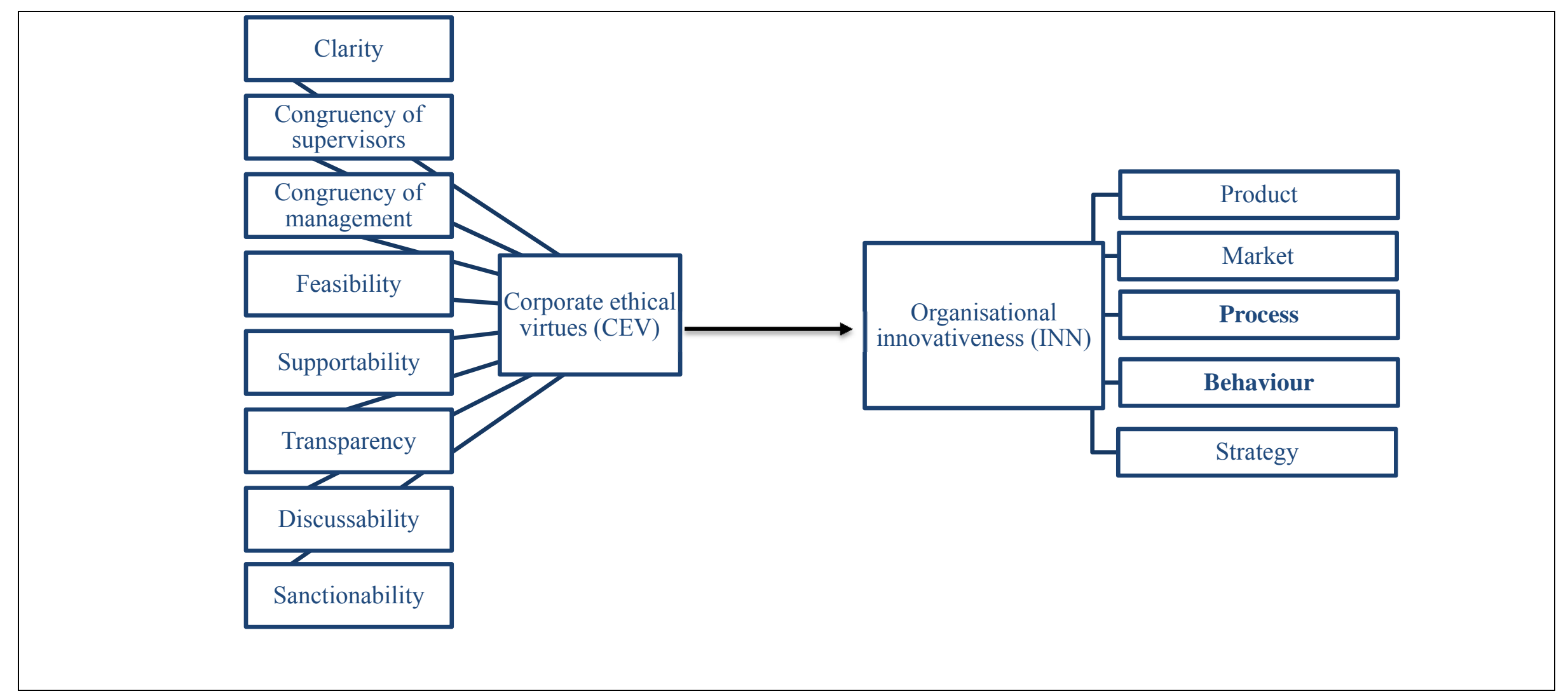

Figure 1. The relationship between ethical organisational culture and organisational innovativeness 
Lithuanian public organisation

Adj. $R^{2}=0.243$

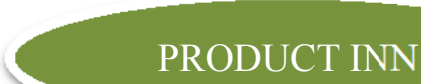

Adj. $R^{2}=0.228$

\section{PRODUCT INN}

MARKET INN

Adj. $R^{2}=0.343$

\section{PROCESS INN}

Adj. $R^{2}=0.415$

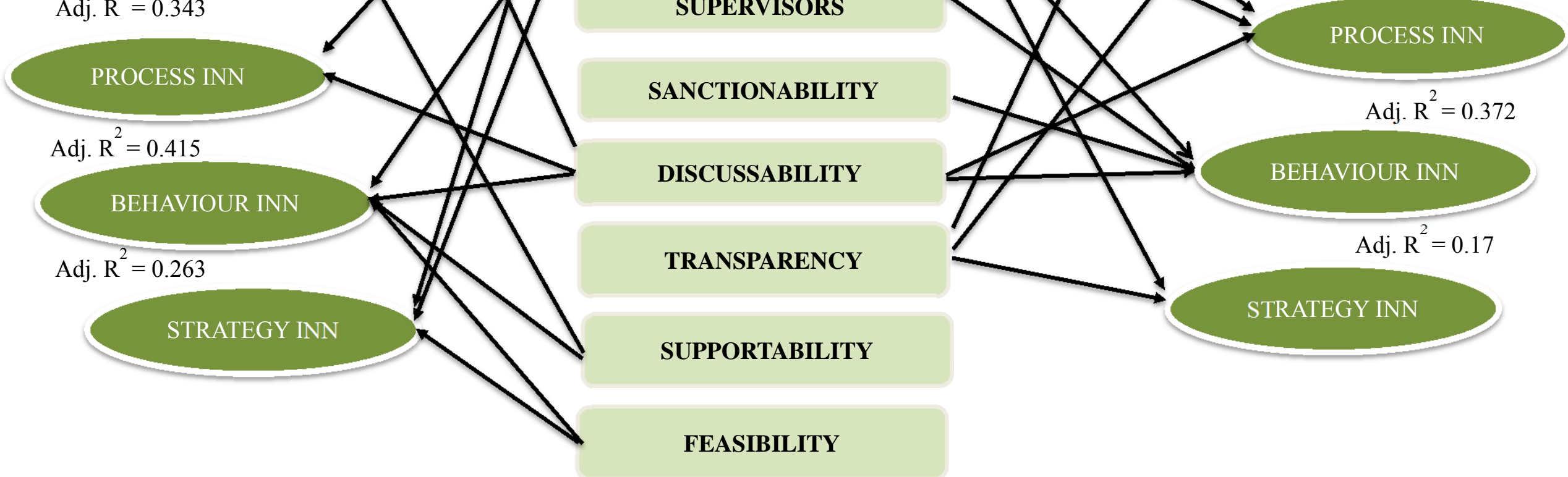

Finnish public organisation

Adj. $\mathrm{R}^{2}=0.073$

Figure 2. Results of regression analysis in the Lithuanian and Finnish public organisations 
Table 1. Finnish and Lithuanian sample characteristics

Finnish sample

\begin{tabular}{l} 
The population \\
\hline Sample size
\end{tabular}

Sample size

Response rate

Gender

\begin{tabular}{lcc}
\hline Gender & & \\
\hline Female & $60 \%$ & $85 \%$ \\
Male & $40 \%$ & $15 \%$ \\
n.i. & $0 \%$ & $0 \%$
\end{tabular}

\begin{tabular}{lcc}
\hline Position* & & \\
\hline Employee & $6 \%$ & $86 \%$ \\
Expert/specialist & $83 \%$ & $10 \%$ \\
Administrative staff & & $3 \%$ \\
Manager/supervisor & $11 \%$ & $1 \%$ \\
n.i. & $0 \%$ &
\end{tabular}

\section{Education}

Academic degree

$78 \%$

$92 \%$

\begin{tabular}{lcc}
\hline Work experience ** & & \\
\hline In current position/ organization (average years) & 13 & 14 \\
Std. Deviation & 9.78 & 7.93 \\
Range & 45 & 41
\end{tabular}

* "Employee" just in the Finnish sample, "Specialist" in the Lithuanian sample, "Expert/specialist" in the Finnish sample, "Administrative staff" just in the Lithuanian sample

** "Position" in the Finnish sample; "Organization" in the Lithuanian sample. 
Table 2. Descriptive findings

\begin{tabular}{|c|c|c|c|c|c|c|c|c|c|c|c|c|}
\hline \multicolumn{7}{|c|}{ Finnish sample } & \multicolumn{5}{|c|}{ Lithuanian sample } & \multirow[b]{2}{*}{$\begin{array}{c}\text { Cronbach's } \\
\alpha\end{array}$} \\
\hline Variables & $N$ & Min & $\operatorname{Max}$ & Mean & $\begin{array}{l}\text { Std. } \\
\text { dev. }\end{array}$ & $\begin{array}{c}\text { Cronbach's } \\
\alpha\end{array}$ & $N$ & Min & $\operatorname{Max}$ & Mean & $\begin{array}{l}\text { Std. } \\
\text { dev. }\end{array}$ & \\
\hline \multicolumn{13}{|c|}{ Organisational innovativeness } \\
\hline PROD & 477 & 1.5 & 7.0 & 4.3 & .919 & .72 & 472 & 1.0 & 7.0 & 4.9 & .936 & .77 \\
\hline MARK & 477 & 1.0 & 5.5 & 3.5 & .745 & .47 & 497 & 1.0 & 7.0 & 5.0 & .948 & .42 \\
\hline BEHA & 477 & 1.0 & 6.5 & 3.9 & 1.151 & .85 & 513 & 1.0 & 7.0 & 4.6 & 1.412 & .85 \\
\hline PROC & 477 & 1.0 & 7.0 & 4.5 & .904 & .71 & 459 & 1.0 & 7.0 & 5.0 & 1.211 & .75 \\
\hline STRA & 477 & 1.0 & 7.0 & 3.6 & .957 & .49 & 389 & 1.0 & 7.0 & 4.6 & 1.149 & .56 \\
\hline ON, total & 477 & 1.8 & 6.5 & 3.9 & .702 & .87 & 291 & 1.0 & 6.7 & 4.9 & .927 & .90 \\
\hline \multicolumn{13}{|c|}{ Ethical organisational culture } \\
\hline CLAR & 477 & 1.7 & 6.0 & 4.9 & .652 & .91 & 510 & 1.8 & 6.0 & 5.2 & .839 & .92 \\
\hline CONS & 477 & 1.8 & 6.0 & 4.8 & .918 & .94 & 620 & 1.0 & 6.0 & 5.2 & 1.091 & .96 \\
\hline CONM & 477 & 1.5 & 6.0 & 4.6 & .884 & .92 & 634 & 1.0 & 6.0 & 5.1 & 1.123 & .93 \\
\hline FEAS & 477 & 1.0 & 6.0 & 4.8 & .782 & .82 & 695 & 1.0 & 6.0 & 4.7 & 1.191 & .84 \\
\hline SUPP & 477 & 1.0 & 6.0 & 3.9 & .952 & .91 & 603 & 1.0 & 6.0 & 4.7 & 1.055 & .90 \\
\hline TRAN & 477 & 1.6 & 6.0 & 3.9 & .751 & .84 & 341 & 1.0 & 6.0 & 4.3 & .957 & .86 \\
\hline DISC & 477 & 1.7 & 6.0 & 4.2 & .871 & .94 & 432 & 1.0 & 6.0 & 4.6 & 1.055 & .94 \\
\hline SANC & 477 & 1.4 & 6.0 & 4.1 & .814 & .90 & 387 & 1.0 & 6.0 & 4.4 & 1.078 & .91 \\
\hline $\mathrm{CEV}$, total & 477 & 2.2 & 5.9 & 4.3 & .634 & .97 & 248 & 1.9 & 5.9 & 4.5 & .827 & .98 \\
\hline
\end{tabular}

Organisational innovativeness: PROD product innovativeness; MARK market innovativeness; BEHA behavioural innovativeness; PROC process innovativeness; STRA strategy innovativeness.

Ethical organisational culture: CLAR clarity; CONS congruency of supervisors; CONM congruency of management; FEAS feasibility; SUPP supportability; TRAN transparency; DISC discussability; SANC sanctionability.

Results of independent samples T-test: The average evaluations of all ON dimensions are statistically significantly different; the average evaluations of all $\mathrm{ON}$ also are statistically significantly different. 
Table 3. Partial correlations with gender as a control variable

\begin{tabular}{|c|c|c|c|c|c|c|}
\hline \multirow[b]{2}{*}{ Country } & \multirow[b]{2}{*}{ Virtues } & \multicolumn{5}{|c|}{ Innovativeness } \\
\hline & & Product & Market & Behaviour & Process & Strategy \\
\hline \multirow[t]{8}{*}{ Finland } & Clarity & $.225 * *$ & $.167 * *$ & $.387 * *$ & $.406^{* *}$ & $.229^{* *}$ \\
\hline & Congruency of supervisors & $.200 * * *$ & .080 & $.472 * * *$ & $.370 * * *$ & $.212 * * *$ \\
\hline & Congruency of management & $.230 * *$ & $.166^{* *}$ & $.531 * *$ & $.525 * *$ & $.398 * *$ \\
\hline & Feasibility & .064 & .040 & $.305^{* *}$ & $.250 * *$ & $.176^{* *}$ \\
\hline & Supportability & $.216^{* *}$ & $.160 * *$ & $.446^{* *}$ & $.402 * *$ & $.297 * *$ \\
\hline & Transparency & $.249 * *$ & $.211 * *$ & $.441 * *$ & $.405 * *$ & $.315^{* *}$ \\
\hline & Discussability & $.202 * *$ & $.181^{* *}$ & $.559 * *$ & $.511^{* *}$ & $.310^{* *}$ \\
\hline & Sanctionability & $.221 * *$ & $.196^{* *}$ & $.563 * *$ & $.472 * *$ & $.336 * *$ \\
\hline \multirow[t]{8}{*}{ Lithuania } & Clarity & $.430 * *$ & $.446^{* *}$ & $.523 * *$ & $.553 * *$ & $.474 * *$ \\
\hline & Congruency of supervisors & $.323 * *$ & $.289 * *$ & $.433 * *$ & $.358 * *$ & $.387^{* *}$ \\
\hline & Congruency of management & $.423 * *$ & $.426^{* *}$ & $.564 * *$ & $.490 * *$ & $.483^{* *}$ \\
\hline & Feasibility & .047 & $.167^{*}$ & .100 & .056 & $.283^{* *}$ \\
\hline & Supportability & $.415^{* *}$ & $.414 * *$ & $.574 * *$ & $.483 * *$ & $.415^{* *}$ \\
\hline & Transparency & $.351 * *$ & $.293 * *$ & $.418 * *$ & $.407 * *$ & $.305^{* *}$ \\
\hline & Discussability & $.433 * *$ & $.366^{* *}$ & $.571 * *$ & $.471^{* *}$ & $.398^{* *}$ \\
\hline & Sanctionability & $.415^{* *}$ & $.333 * *$ & $.552 * *$ & $.479 * *$ & $.451 * *$ \\
\hline
\end{tabular}

$* * * \mathrm{p}<0.001, * * \mathrm{p}<0.01, * \mathrm{p}<0.05$ 
Table 4. Regressions

\begin{tabular}{|c|c|c|c|c|c|c|c|c|c|c|c|c|}
\hline Dependent variable & \multicolumn{2}{|c|}{ ON } & \multicolumn{2}{|c|}{ PROD INN } & \multicolumn{2}{|c|}{ MARK INN } & \multicolumn{2}{|c|}{ PROC INN } & \multicolumn{2}{|c|}{ BEHA INN } & \multicolumn{2}{|c|}{ STRA INN } \\
\hline \multicolumn{13}{|c|}{ Finland } \\
\hline Adj. $\mathrm{R}^{2}$ & \multicolumn{2}{|c|}{.322} & \multicolumn{2}{|c|}{.073} & \multicolumn{2}{|c|}{.043} & \multicolumn{2}{|c|}{.326} & \multicolumn{2}{|c|}{.372} & \multicolumn{2}{|c|}{.170} \\
\hline Constant & \multicolumn{2}{|c|}{$9.912 * * *$} & \multicolumn{2}{|c|}{$10.439 * * *$} & \multicolumn{2}{|c|}{$15.114 * * *$} & \multicolumn{2}{|c|}{$4.515^{* * *}$} & \multicolumn{2}{|c|}{-.872} & \multicolumn{2}{|c|}{$5.38 * * *$} \\
\hline \multirow[t]{4}{*}{ Independent variables (Betas) } & CONGM & $.313^{* * *}$ & TRAN & $.185 * * *$ & TRAN & $.211 * * *$ & CONG M & $.307 * * *$ & SANC & $.193 * *$ & CONGM & $.323 * * *$ \\
\hline & SANC & $.194 * *$ & CLAR & $.136 * *$ & & & DISC & $.240 * * *$ & CONGM & $.205 * * *$ & TRAN & $.142 * *$ \\
\hline & TRAN & $.147 * *$ & & & & & CLAR & $.117^{*}$ & DISC & $.197 * *$ & & \\
\hline & & & & & & & & & CONG S & $.107 *$ & & \\
\hline \multicolumn{13}{|c|}{ Lithuania } \\
\hline Adj. $\mathrm{R}^{2}$ & \multicolumn{2}{|c|}{$\begin{array}{c}.487 \\
6110 * * *\end{array}$} & \multicolumn{2}{|c|}{.243} & \multicolumn{2}{|c|}{$\frac{.228}{7.806 * * *}$} & \multicolumn{2}{|c|}{.343} & \multicolumn{2}{|c|}{.415} & \multicolumn{2}{|c|}{.263} \\
\hline Constant & \multicolumn{2}{|c|}{$6.119 * * *$} & \multicolumn{2}{|c|}{$6.515 * * *$} & \multicolumn{2}{|c|}{$7.896 * * *$} & \multicolumn{2}{|c|}{$3.618^{* * *}$} & \multicolumn{2}{|c|}{$2.304^{*}$} & \multicolumn{2}{|c|}{$5.089 * * *$} \\
\hline \multirow[t]{4}{*}{ Independent variables (Betas) } & CONGM & $.501 * * *$ & CLAR & $.263 * * *$ & CLAR & $.293 * * *$ & DISC & $.194 * *$ & CONGM & $.290 * * *$ & CONGM & $.279 * * *$ \\
\hline & CLAR & $.382 * * *$ & DISCUS & $.287 * * *$ & SUPP & $.229 * *$ & CLAR & $.442 * * *$ & DISC & $.200^{*}$ & CLAR & $.223 * *$ \\
\hline & CONGS & $-.342 * *$ & & & & & & & SUPP & $.262 * *$ & FEAS & $.135^{*}$ \\
\hline & SUPP & $.188^{*}$ & & & & & & & FEAS & $-.127 *$ & & \\
\hline
\end{tabular}

$* * * \mathrm{p}<0.001, * * \mathrm{p}<0.01,{ }^{*} \mathrm{p}<0.05$ 